\title{
Risk factors of hepatic graft failure, morbidity and mortality after living donor liver transplantation (LDLT): Review Article
}

\author{
Ayman Azzam* \\ Department of General Surgery, Alexandria University, Alexandria, Egypt
}

\begin{abstract}
Back ground: Liver transplantation is a breakthrough in the modern life. With the increase demands on liver transplantation, LDLT was emerged. With more increase in the demands, the donor pool started to be widened and the use of marginal donors started. The factors affect the graft failure become widened and included multiple factors.

Aim and objective: This review extensively put the focus on the risk factors for hepatic graft failure after LDLT. Also, the impact of these factors and their influence on the patients' morbidity and mortality.

Conclusion: Multiple factors were studied as risk factors for graft failure and patients' mortality after LDLT. The rate of early graft failure is low. This is due to optimum donor selection as regards age, sex, body mass index (BMI) and ABO-compatibility; computer-assisted planning and decision making in donor segmental hepatectomy and optimum GRWR; short cold ischemic time; high level of expertise in the center; and timely detection of vascular, biliary and immunological complications responsible for early graft failure together with early and efficient management. Most of the underlying risk factors for late graft failure include patients with $\mathrm{CR}$ which were not responding to treatment and patients with disease recurrence which is unavoidable. Therefore, both these complications constitute real problems in liver transplantation.
\end{abstract}

\section{Introduction}

Liver transplantation (LT) represents the only curative treatment for patients with end-stage liver disease. With improvements in surgical techniques and advances in immunosuppressive therapy, LT has become routine procedure during the past decades [1]. As indications for orthotopic LT have widened [2,3], the need for transplantable organs has increased. Unfortunately, the supply of deceased donor organs has not met the increasing demand. Therefore, expanding the donor pool and reducing waiting list mortality is one of the major challenges today for the liver transplant community [4]. Increasing the frequency of living donor liver transplantations (LDLT) meets both of those challenges $[5,6]$. With scarcity of deceased donors, LDLT has become the main form of LT especially in Asian countries [7,8]. The success of LDLT in the pediatric population led to improvement of this technique for adult population [9]. Adequate selection of both the donor and the recipient for LDLT are very important factors to prevent mortality and morbidity including graft failure and the need for retransplantation $[10,11]$. Few studies have investigated factors leading to graft failure especially with LDLT $[12,13]$. Several risk factors for graft loss after LDLT were identified by researchers as donor age [14], MELD score [15-19], intraoperative blood loss [19-21], warm ischemic time [21], and small for size syndrome [22-25]. Other studies investigated the factors responsible for graft loss and retransplantation namely hepatic artery thrombosis [26,27] primary non-function [26] and hyperacute rejection [28]. Although improving outcomes and survival after LDLT with meticulous selection criteria $[9,29]$, still no definite criteria can predict graft dysfunction or failure.

\section{Graft type and size}

In LDLT, the choice of the type and size of the graft is one of the most important aspects of the procedure.

\section{Graft size}

Although the safety limit of residual liver volume for donor has not been precisely estimated, it was believed that a normal liver could tolerate right hepatectomy as the residual left lobe constitutes 30.0$40.0 \%$ of the total liver mass which is considered safe for the donor [30]. Based on this concept, right lobe graft program was introduced in Kyoto University in February 1998 [31]. In cases where segment 5 and 8 of the right lobe drain mainly in the middle hepatic vein (MHV), right lobe grafts including the MHV (extended right lobe graft) was resorted to, to prevent the congestion of these segments and preserve the functional volume of the right lobe graft and to prevent the occurrence of smallfor-size syndrome in the recipient [32]. The increasing use of the extended right lobe grafts was due to the realization of the importance of the inclusion of this vein in the graft whenever it does not affect the venous drainage of residual liver volume in the donor.

*Correspondence to: Ayman Azzam, Department of General Surgery, Alexandria University, Alexandria, Egypt, E-mail: aazzam70@yahoo.com

Key words: risk factors of hepatic graft failure, morbidity and mortality, LDLT

Received: October 12, 2018; Accepted: November 20, 2018; Published: November 23, 2018 
After the extension of the indications for LDLT to adults, the problem of "small-for-size graft" was encountered. This problem is not found in either cadaveric liver transplantation or in pediatric LDLT. This was partly solved by the introduction of the right lobe graft [31]. However, some cases with right lobe grafts developed poor bile production, delayed synthetic function, prolonged cholestasis and intractable ascites in spite of adequate graft volume. As these symptoms indicate poor graft function in presence of optimum graft volume, it was given the name of "small-for-size syndrome" [33]. Therefore, the "small-for-size syndrome" can be observed not only in "small-forsize graft" but also in optimum or even in large size grafts. Several explanations were introduced to clarify this syndrome and researches where conducted to solve this fatal problem [23]. Several techniques are being explored and innovated in an attempt to ameliorate the impact of small-for-size syndrome. One of the procedures is to obtain larger liver mass by addition of grafts such as auxiliary partial orthotopic LDLT (APOLT) [34], but it has a lot of complications and dual liver grafts $[35,36]$, which is not common as it needs the presence of two available donors which is not always feasible. Other procedures included the MHV to the right lobe graft which may not add liver volume but can improve the graft function by prevention of the congestion of the anterior segment [37]. Injury of the graft may be produced by persistent portal hypertension and portal over perfusion of the graft [38]. Control of portal pressure and graft perfusion may be adopted to prevent graft injury in such cases. This was achieved by innovative techniques such as splenic artery ligation (SPL) $[39,40]$, or permanent portacaval (PC) shunt $[41,42]$.

\section{Graft type}

Hepatic steatosis evolved as a risk factor in LDLT. There is consensus that macrosteatosis affects liver graft function and survival more than microsteatosis because it may progress to non-alcoholic steatohepatitis (NASH) and ultimate liver cirrhosis with graft failure [43-46]. Its presence is suspected in overweight or obese donors with a body mass index (BMI) $\geq 25 \mathrm{~kg} / \mathrm{m}^{2}$ [47]. In such donors, CT and ultrasound can be used to estimate hepatic fat [48]. Donors with steatosis have a reduced functional liver mass. It has been proposed that each percentage of hepatic steatosis in the donor decreases the functional graft mass by $1 \%$ [49]. This must be factored into the calculation of GRWR. In cadaveric liver transplantation, steatosis has been associated with primary non-function (PNF) and initial poor function that is recoverable $[43,44,46]$. PNF occurs in as many as $80 \%$ of patients with severe steatosis and therefore grafts with more than $60 \%$ steatosis represent a contraindication to transplantation [43,50,51]. Initial poor function occurs in approximately $30 \%$ of patients receiving livers with moderate steatosis [51]. Several groups have shown that grafts with less than $30 \%$ steatosis have results similar to those of transplantation with non-steatotic livers [45,52-54]. In LDLT, Hayashi evaluated the effect of steatosis on graft outcomes and found that grafts with mild to moderate steatosis demonstrated slight disturbances in early graft function, but were similar to controls [55]. Grafts with severe steatosis were associated with poor function and outcome [55]. Similarly, Soejima evaluated the impact of the degree of steatosis in 60 consecutive donors and recipients. One-year graft survival in none, mild and moderate steatosis groups was comparable $(85.9 \%, 80.7 \%$, and $80.0 \%)$. He concluded that grafts with moderate steatosis $(<50 \%)$ can be used if the residual volume in the donor is at least $40 \%$ to avoid additional risk related to steatosis [56]. Cho reported similar regeneration ability and early outcome between recipients receiving mild steatotic $(\leq 30 \%$ macrosteatosis) vs. normal ( $\leq 5 \%$ macrosteatosis) liver grafts. Using biopsies performed 10 days after surgery, he noted that the degree of steatosis decreased to less than $10 \%$ in all grafts suggesting that mild steatosis is rapidly reversible after LDLT [57]. Although the use of grafts with mild to moderate steatosis yields comparable results with those without steatosis, it appears risky to use such grafts on a routine basis. Their use are justified when they are not associated with other risk factors. It is recommended that donors with BMI $\geq 25$ should undergo diet control and exercise which permit reduction of liver steatosis allowing a delayed but safer transplantation for both donors and recipients. Liver biopsy is recommended in countries where there is lack of expertise in the evaluation and diagnosis of hepatic steatosis by radiological means. It also serves to detect other pathological conditions in the donor such as hepatitis, fibrosis or cirrhosis, which may be prevalent in these countries. PNF, which is common in cadaveric liver transplantation, did not occur in the present series most likely due to the short cold ischemic time (CIT) in LDLT.

Hepatic grafts from ABO-incompatible donors: is considered as a risk factor in LDLT because of the risk of hyperacute rejection mediated by preformed anti-ABO antibodies [58-60]. ABO-incompatible donors may be the only available source of graft in life threatening situations such as in fulminant hepatic failure (FHF). In countries with limited access to cadaveric donors, the use of grafts from $\mathrm{ABO}$-incompatible living donors occurs more frequently, particularly when the donor source is restricted to immediate relatives [61,62]. Plasmapheresis is effective in decreasing pre-transplantation antibody titers, but it is ineffective in maintaining low post-transplantation antibody titers and fails to prevent death of the patient once hepatic necrosis occurs. Yandza demonstrated that children less than 2 years old had lower anti-ABO antibodies titers and lower morbidity compared to adults [63]. Gugenheim suggested that ABO-incompatible liver transplantation is only justifiable in adult recipients as an emergency [58]. On the contrary, Hanto reported encouraging results in adults [64]. In ABO-incompatible liver transplantation from cadaveric donors, the incidences of preoperative mortality, arterial thrombosis and irreversible rejection and the rate of retransplantation have been reported to be greater than those in ABO-compatible or-identical transplants, irrespective whether the cases were adult or pediatric, emergency or elective transplantation and regardless of the indication for transplantation [58,65-67]. Gordon found reduced graft survival rate in $\mathrm{ABO}$-incompatible liver transplantation from cadaveric donors. Therefore, liver transplantation from $\mathrm{ABO}$-mismatched cadaveric donors has been thought to be justified only in emergency cases especially in children, due to the shortage of appropriate donor grafts [68]. Farges has reported that hyperacute rejection is a complication in adult patients undergoing $\mathrm{ABO}$-incompatible cadaveric liver transplantation [61]. Renard and Andrews also reported hepatic necrosis with hemorrhagic and perivascular parenchymal collapse in pediatric cases [69]. A difference in outcome between adult and pediatric cadaveric liver transplantation has been reported, with pediatric transplants being more successful [70,71]. The reasons for more favorable outcome in children are not totally clear [72,73], but they may be related to lower anti-ABO antibodies levels, [63], or to an immature complement system [74] thus, the factors that initiate hyperacute rejection are absent during early infancy. In contrast, adults undergoing splenectomy in $\mathrm{ABO}$-incompatible liver transplantation to decrease the incidence of hyperacute rejection together with the addition of other immunosuppressive agents in such cases also might contribute to poor outcome in these patients [68,71]. Some centers showed insignificant difference in the results of $\mathrm{ABO}$-incompatible and ABO-compatible grafts as regards the graft failure in LDLT which 
can be attributed to the ABO-incompatibility protocol adopted in these centers [75-78]. Although ABO incompatible LDLT may be carried out with relative safety in infants $<1$ year old using standard immunosuppression, yet, it carries increased risk of graft failure in older patients and should be used only in urgent cases and/or when they are the only available donors.

The donor age and sex: as risk factors in liver transplantation were extensively studied in world literatures. Pittsburgh group studied the effect of donor age and sex on the outcome of grafts in cadaveric liver transplantation. They found that the effect of donor age became evident only when they were older than 45 years. They also found that livers from female donors yielded significantly poorer results, with 2-year graft survival of female donor to male recipient, 55\% (range $45 \%$ to $67 \%$ ); female donor to female recipient, $64 \%$ (range $54 \%$ to $77 \%$ ); male donor to male recipient, $72 \%$ (range $66 \%$ to $78 \%$ ); and male donor to female recipient, $78 \%$ (range $70 \%$ to $88 \%$ ) [79]. Ikegami studied the impact of donor age on LDLT. He found that the liver grafts obtained from middle aged (30-50 years old) and older aged donors ( $>50$ years old) recovered their volumes as much as $80 \%$ of standard liver volume (SLV) at 1 month, whereas those of younger donors ( $<30$ years old) accelerated volume recovery and also reach as much as $80.0 \%$ of SLV in only 1 week after transplantation. These results denote that liver regeneration occurs earlier and proceeds more rapidly in younger livers than in older livers. He also found significant prolongation of prothrombin time values in POD 3 in the grafts obtained from aged donors than those from younger ones [80]. Kimura also reported reduced capacity in protein synthesis in hepatic grafts obtained from aged donors [81]. Old age and female gender should be considered as risk factors in LDLT. They are considered more risky if they are additive such as in old female donors. However, they should not be discarded from donation in the face of shortage of liver donors.

\section{Recipient factors}

The recipient status at the time of transplantation: United Network for Organ Sharing (UNOS) status: is considered as a risk factor for both graft and patient survival. FHF, which belongs to United Network for Organ Sharing (UNOS) status 1, has reported mortality rate between $70-95 \%$ in children depending on the cause of the disease and the age of the patient [82]. Because progression of organ failure and irreversible neurologic damage may occur in pediatric patients with FHF while awaiting a cadaveric allograft, it is crucial that early LDLT be performed without excessive delay in waiting for cadaveric grafts. LDLT as a mode of therapy in FHF in children was first attempted by Tanaka in 1994 [83], who reported on 3 pediatric patients with FHF, all of them received left lobe liver grafts estimated to be $0.8-1.0 \%$ of the body weight and were successfully discharged from the hospital. In 1998, the same group reported their results in a series of 11 children with survival rate of $73.0 \%$ after a mean follow-up of 28 months (range 13-67 months) [84]. Similar results were reported in pediatric patients from both Eastern [85] and Western centers [86]. Mack in 2001 reported a retrospective study on 19 pediatric patients with FHF associated with multiple organ failure (MOF) comparing the results of LDLT to a similar group of patients who received cadaveric allograft donation (CAD). Patients in the LDLT group had markedly improved survival compared with the CAD group. Thirty-day and six-month survival rates of the LDLT group were $88.0 \%$ and $63.0 \%$ compared with $45.0 \%$ and $27.0 \%$ in the CAD group, respectively. He suggested that the difference in survival outcomes was related to the fact that LDLT recipients had decreased waiting times for transplantation and decreased cold ischemia time as compared with the CAD recipients
[87]. The application of LDLT in FHF in adults was first addressed by Lo in 1999 who reported that when cadaveric organ donation is scarce, emergency LDLT can be applied to high urgency adult patients [88]. Nishizaki suggested that a high success rate of LDLT and low donor risk could be achieved in adult patients with FHF using a left lobe graft. He reported 15 adult patients with FHF treated with a left lobe graft which corresponded to $23.0-54.0 \%$ of recipients' standard liver volume. The overall survival rate was $80.0 \%$ with a follow-up period from 3-43 months. He also reported no significant differences in survival outcomes comparing the patients with a liver graft to a standard liver volume ratio of $<30.0 \%$ and those with a ratio of $\geq 30.0 \%$ [89]. In the lights of these studies, it appears that, the results of LDLT in adult patients with FHF were superior to those in pediatric patients. The difference may be related to the cause of the disease, incidence of rejection and the rate of postoperative complications. Testa reported the results of 7 patients who had acute-on-chronic liver failure and underwent urgent LDLT using right lobe grafts. Patient and graft survival rates were only $43.0 \%$ at a mean follow-up of 15.1 months [90].

Regarding MELD score: as a risk factor for hepatic graft failure. Freeman in 2003 [91] showed that little lifetime benefit for the recipient is achieved with MELD scores less than 10 and perhaps less than 14 . The relative risk for post-transplantation mortality starts to increase for candidates with MELD score greater than 25 at the time of transplantation. Therefore, candidates with MELD score between 1425 would appear to derive the most lifetime benefit. These would seem to be the ideal candidates for adult LDLT.

\section{Indication of LDLT}

\section{Hepatitis B virus related liver disease}

Liver transplantation in patients with HBV-related liver diseases is followed by a high incidence of recurrent graft infection and subsequent graft failure [92]. As a result, many transplant centers were reluctant to consider patients with HBV-related liver diseases for transplantation. After the introduction of the prophylaxis protocol against $\mathrm{HBV}$ recurrence using a combination of high-dose of HBIG and lamivudine by Markowitz, the results began to improve. He reported on 4 of 10 patients which were HBV-DNA positive before transplantation, all were negative for HBsAg and HBV-DNA at a median follow-up of nearly 1 year [93]. In order to reduce the financial burden of high-dose life-long HBIG, the use of sequential HBIG therapy for 2 years after transplantation followed by lamivudine monotherapy has been shown to be effective in preventing reinfection in patients with a low level of pretransplant viral replication [94].

\section{Hepatitis $C$ virus related liver disease}

Liver transplantation in patients with chronic end-stage liver disease caused by chronic HCV-related cirrhosis are reported to be followed by severe graft damage in cadaveric liver transplantation and even more in LDLT $[95,96]$. It is suggested that the cause of graft damage is the recurrence of $\mathrm{HCV}$ infection in the graft. The recurrence of the disease is diagnosed by the presence of elevated ALT, detected HCV-RNA and liver biopsy [97]. An analysis of the UNOS database demonstrated significantly diminished 5-year survival after primary transplantation in HCV-positive patients [98]. The transplant group in the University of California at Los Angeles (UCLA) observed recurrent hepatitis in 86.0\% of HCV-infected LDLT recipients compared with only $30.0 \%$ of cadaveric transplant recipients. The mean time to $\mathrm{HCV}$ recurrence was 4.75 months [95]. Similar outcomes were reported from Colombia University group who reported $80.0 \%$ of LDLT recipients developed 
recurrent $\mathrm{HCV}$ compared with $58.0 \%$ of cadaveric recipients ( $\mathrm{p}$ value $<0.05$ ) with mean follow-up of 19 months [96]. It is known that HCV recurrence and progression to fibrosis is enhanced by the use of boluses of methylprednisolone in the management of acute rejection [99]. In order to decrease the rate of recurrence and progression of HCV, Kyoto group began a protocol of steroid free immunosuppression in cases of HCV end-stage liver failure recipients. A monotherapy of tacrolimus without mycophenolate mofetil was used because it has been demonstrated that the administration of mycophenolate mofetil could result in a more sever recurrence [100]. The key point in the management of transplanted patients affected with HCV infection is the regular follow up of transplanted patients to detect early recurrence by PCR and the application of the treatment protocol to guard against the development of liver cirrhosis in the graft and subsequent failure. It is suggested that treatment of LDLT recipients before transplantation may prevent HCV recurrence after transplantation [101]. In a study involving 21 patients receiving a prophylactic treatment by interferon (IFN) and ribavirin (RBV), liver histology was normal in $81.0 \%$ of patients one year after transplantation, and virological clearance was observed in $41.0 \%$ of patients [102]. Leucopenia and thrombopenia were noted in all studies and resulted in dose reduction in some patients. Moreover, in the early report of Feray, chronic rejection may occur in patients under treatment [103].

\section{Hepatocellular carcinoma}

LT in HCC is thought to be a better therapy as compared with resection. This thinking was dependent on the fact that more than $90.0 \%$ of cases develop HCC in the setting of underlying liver cirrhosis, most commonly due to chronic hepatitis B or C [104,105]. Resection in such cases is followed by a high rate of development of secondary lesions within few years because of the multicentricity of the tumor [106]. Transplantation is a logical approach in this situation as it can potentially cure both cirrhosis and HCC $[107,108]$. One of the major downfalls of cadaveric liver transplantation as a treatment for HCC is that patients must wait for a liver $[109,110]$. This waiting time compromises the outcome of transplantation because of the disease progression may occur during the waiting time. The recent development of adult LDLT provided an alternative source of donor livers for transplantation, which is independent on the waiting time or UNOS criteria. For a patient who has a living donor, a donor organ is not a scarce resource $[111,112]$. Current selection criteria in cadaveric donor programs are based on a retrospective analysis of tumor characteristics and allocate transplant only to those patients who satisfy Milan criteria [113]. These criteria provide transplantation outcomes that are similar to those of transplantation in patients without HCC. These criteria are based on tumor size and number. Single tumors must be $<5 \mathrm{~cm}$ in diameter, if more than one lesion is present, the maximum number of tumors must be 3 or less and none of them is $>3 \mathrm{~cm}$ in diameter. The rationale behind the use of these criteria is to preserve the outcome in HCC as compared with non-HCC patients so that organ use is optimized [114]. Because LDLT has been a successful and fully accepted treatment for adult patients with end-stage liver disease, interest in this modality as the treatment for HCC has risen. More liberal criteria has been suggested based on the premise that the outcomes of these expanded criteria are similar to those of the more conservative criteria in terms of posttransplantation survival [115-117]. Based on these studies, LDLT was proposed for expanded criteria with little adverse effect on outcome. The pilot study on LDLT for HCC was started in February 1999 in Kyoto University with an approval from the institutional ethical committee with inclusion criteria consisting of otherwise untreatable
HCC with complete exclusion of extra-hepatic lesion or macroscopic vascular invasion, irrespective of tumor size and number [13,118]. Some studies demonstrated favorable results in the patients fulfilling these selection criteria and concluded that Milan criteria do not seem to be suitable for selecting HCC patients for LDLT [118,119]. Similar results were reported by Yao, who concluded that the Milan criteria may be expanded with excellent survival in LDLT [120]. From these studies, it is clearly demonstrated that patients with HCC outside the Milan criteria and excluded from cadaveric donor transplantation could survive nearly the same as patients with HCC within Milan criteria in LDLT programs. Therefore, the application of the Milan criteria for all patients with HCC would have denied many patients who can survive after transplantation. Therefore, transplantation is by far the best treatment option for patients with HCC, if a careful search reveals no extra-hepatic disease. In LDLT programs, where the patient has his special living donor, the UNOS and Milan criteria are not necessarily relevant.

\section{The technique of LDLT}

LDLT, regarding the technique, is a complex operation as compared to cadaveric LT. A thorough understanding of the segmental anatomy of the liver, the hepatic arterial, hepatic venous, portal venous and biliary ductal systems and the ability to recognize variants in this anatomy are critical to perform LDLT successfully and safely. Various anatomic variations encountered during this procedure has been detailed through careful dissection of cadaveric livers and examination of hepatic corrosion casts [121-123]. In spite of that, many technical complications are still reported in different centers and may be serious enough to lead to both graft failure and death. Hepatic artery thrombosis (HAT) is the most common and the most critical vascular complication [124-126]. It occurs in $12.0 \%$ of adult and more than $40.0 \%$ of pediatric recipients $[126,127]$. HAT leads to hepatic necrosis, biliary leakage or strictures and finally recurrent sepsis [128]. Early diagnosis with prompt intervention is essential because urgent retransplantation is required in most cases. Hepatic arterial stenosis (HAS) can be observed in $11.0 \%$ of liver recipients. It is usually localized at the site of anastomosis. In most cases, it is caused by technical failure which is responsible for damage of the vascular intima with subsequent necrosis and scar formation. Tight anastomosis can reduce blood flow, which favors arterial thrombosis. In some cases arterial stenosis per se represent an indication of retransplantation [129]. Portal vein thrombosis (PVT) is one of the life threatening complications of liver transplantation, especially when occurs in the immediate postoperative period [130,131]. Acute PVT may lead to portal hypertension or hepatic ischemia with catastrophic sequelae. Late-onset PVT, on the other hand, is generally well tolerated, although it may eventually lead to graft compromise requiring aggressive intervention [132]. Portal vein stenosis (PVS) usually develops slowly after transplantation, and it is suggested by the presence of gastrointestinal varices, ascites and splenomegaly. It is diagnosed by Doppler ultrasonography in asymptomatic cases [133]. Thrombosis or stenosis of the portal venous trunk may be observed in $1.0 \%$ to $12.5 \%$ liver recipients $[126,133,134]$. Abnormal blood flow through the portal vein may be caused by technical error, coagulation disorders, previous surgical interventions (splenectomy) or damage of the endothelium of the portal vein during cannulation $[126,127,134]$. Hepatic venous outflow obstruction may occur due to stenosis and/or thrombosis mainly at the anastomotic site or sites. Several potential mechanisms could be implicated as the cause of anastomotic hepatic vein stenosis. Technical failure is the most likely cause such as tight anastomosis causing purse-string phenomenon, 
stitches catching the back wall or additional stitches for hemostasis. Twisting of the outflow vessel of the left lobe graft secondary to its displacement to the empty right liver fossa occurring upon closure of the abdominal wall may be another cause of hepatic venous outflow obstruction [135]. A third cause may be the structural stenosis of the hepatic vein secondary to enlargement of the graft during the process of regeneration. Hepatic venous outflow obstruction may lead to cirrhosis of the graft if such obstruction continues to be present for a long time. The recent introduction of microsurgical techniques for arterial anastomosis in LDLT has greatly reduced the incidence of HAT compared with previous reports $[60,135]$. From these studies it was concluded that vascular thrombosis occurs mostly during hospital stay and may be responsible for early graft failure, while vascular stenosis appeared late in increasing frequency as the period of follow up increases and may be responsible for of late graft failure [136].

\section{Biliary complications as a risk factor}

Biliary complications after LDLT continue to be the most frequent cause of morbidity and may contribute to mortality of recipients. Complications in the form of biliary leaks, bilomas and strictures were reported to occur with an incidence of $10.0 \%$ to $30.0 \%$ [137-140]. These complications were mostly attributed to ischemia and technical failures [141]. Owing to the prevalence of biliary complications in LDLT, preventive measures were suggested to decrease the rate of these complications. As it is known that ischemic changes around the anastomosis is a major cause of anastomotic stenosis, greater precaution should be taken to preserve the peribiliary plexus around the resected bile duct in the donor.

\section{Hepatic allograft rejection as a risk factor}

Despite recent improvements in immunosuppressive therapy, hepatic allograft rejection remains a major cause of morbidity and graft loss in patients undergoing LT [142-145]. Humoral rejection (HR) is a rare complication that occurs early after transplantation and is usually fatal. There is no specific treatment for HR and the only way to save the life of the patient is urgent retransplantation. Therefore, prevention of the condition is essential and may be attained through the selection of $\mathrm{ABO}$-identical or $\mathrm{ABO}$-compatible donors, if possible. Chronic rejection (CR) is an indolent, but progressive form of allograft injury that is usually irreversible and eventually results in the failure of most vascularized solid organ allografts. It is reported that by five years after transplantation, it affects as many as $30-50 \%$ of heart, lung, pancreas and kidney allografts recipients, but only $4-8 \%$ of patients who undergo liver transplantation [146]. Liver allografts also differ from other solid organs in that CR is potentially reversible. This quality has been generally attributed to liver unique immunobiological properties and the regenerative capacity of bile ducts which are one of the main targets in CR [147-149]. CR can occur within 3 weeks after liver transplantation and was given the name of acute vanishing bile duct syndrome [150]. but commonly occurs after 2 months and usually within 1 year [151,152]. Late onset (later than 1 year) CR is typically seen in inadequately immunosuppressed recipients, either as a result of non-compliance or intentionally attenuated immunosuppression [151]. If the findings indicate a late stage of CR, retransplantation is preferable to too-potent immunosuppression, which may cause fatal infectious complications [151]. CR of a liver allograft may be reversible to some extent. This result was reported in world literature $[147,148,153,154]$. This reversibility usually occurs before the duct loss or obliterative arteriopathy have become severe. Some patients with $\mathrm{CR}$ was found to have experienced one or more episodes of
ACR. This may evolve directly from inadequately controlled ACR episodes as reported in some literatures $[142,154,155]$. The results also show a lower incidence of CR in liver allografts compared to other vascularized allografts. This has been explained by the immunological theories of the so called hepatic tolerogenesity [156]. Graft-versus-host disease (GVHD) is a rare complication that occurs after LT. Smith reported 12 cases of GVHD among 1082 LT done between 1991 and 1998 at Baylor University Medical Center [157]. GVHD is usually a fatal disease and future approaches should focus on its prevention. This can be achieved by HLA matching before LDLT because the donors of all cases of GVHD were of HLA homozygous. Additional risk factors were reported by other authors and include, recipients older than 65 years and recipients of donors more than 40 years younger than the recipients [157].

\section{Infection as a risk factor}

The problem of infection in the setting of LT is among the most serious and difficult complications that follow a technically successful LT. Currently infection is the major cause of death after LT [158]. Recipients are susceptible to infections that are normally controlled by the body's intrinsic defense mechanisms. Obligate immunosuppressive therapy required for the prevention and treatment of rejection constitute a major risk factor in these patients and pave the way for opportunistic bacteria, viruses or fungi to cause infections in such patients. The incidence of bacterial infections after LT differs considerably among transplantation centers and ranges between $35.0 \%$ and $68.0 \%$ [159163]. The timing of bacterial infection showed that most bacterial infections occurred in the immediate postoperative period and during the hospital stay. The high occurrence of bacterial infections in the early postoperative period was reported in different centers of LD $[161,163]$. This may be explained by the intense immunosuppressive therapy given during this period to prevent rejection and the presence of bacteremia induced by intra-tracheal tubes, urinary catheters and intravenous lines. Additionally, ischemic and biliary complications of the graft occur more during this period. The danger concerning bacterial infections in LT lies in the difficulty of diagnosis. The usual signs and symptoms of infection may be masked or absent as a result of the patient's immunosuppressed condition [164]. In addition, clinical manifestations of graft ischemia or graft rejection can mimic those of infection. Bacterial infections can be severe enough to result in septic shock, multiple organ failure (MOF) and death. The incidence of invasive fungal infection was reported to be lower than in other centers which reported a range between $4.0 \%$ - 48.0\% [165-167]. Mortality rate was reported to be $50.0 \%$ to $80.0 \%$ in the presence of fungal infection $[163,165,168]$. They stated that prolonged operative time, increased intra-operative transfusion requirements, choledochojejunostomy, prolonged hospitalization, graft failure and retransplantation, vascular and gastrointestinal complications, recurrent bacterial infections and extended use of antibiotics beyond the first week after transplantation were risk factors for the development of fungal infection. They recommended the prophylactic use of intravenous amphotericin B to prevent postoperative fungal infection in these patients. Cytomegalovirus (CMV) infection was reported to be $18.0 \%$ to $40.0 \%$ of patients $[169,170]$. Most of CMV infection occurs early usually between 3 and 8 weeks after LT [171-173]. The early occurrence of CMV infection may be related to the intense immunosuppressive therapy during this period to prevent or treat episodes of rejection. Epstein bar virus (EBV) infection came next in frequency to CMV infection. More cases of EBV infection occur late after patient discharge. The real problem in EBV infection is that it is a $\mathrm{B}$ cell 
lymphotropic virus capable of inducing proliferative changes leading to post-transplantation lymphoproliferative disorder (PTLD) and frank lymphoma. Over-immunosuppressive therapy was considered as a risk factor in the development of PTLD. Therefore, these patients responded well to cessation of immunosuppression together with large doses of intravenous acyclovir. Accurate diagnosis and early treatment of EBV infection remain elusive to guard against development of EBVassociated PTLD. Sometimes this management is not sufficient and the disease may result in patient death [174].

\section{Disease recurrence as a risk factors}

Disease recurrence has emerged as an area of major concern as patient survival has increased after LD. Recurrence rates vary greatly depending on the primary liver disease. The majority of conditions for which patients undergo transplantation will recur at some point in time, because a number of end-stage liver diseases are due to host or environmental factors [175-177]. On the other hand, most metabolic liver diseases do not recur after transplantation because they are mainly restricted to the liver and can be said to be truly cured. Some studies found that recurrent disease after LT occurred in $10.0 \%$ of long-term survivors $[157,178]$. The rate of disease recurrence increases as the period of follow up increases. Certain factors have been reported to result in increased rate of $\mathrm{HCV}$ recurrence such as high viral load, increased donor age and in the setting of LDLT rather than cadaveric liver transplantation [179]. Combination therapy by PEG-IFN and ribavirin may be well tolerated and beneficial during recurrent HCV infection in liver transplant patients [180]. Recurrence of HBV was reported to occur in $40.0 \%$ of patients who undergo liver transplantation and the virus develops resistance to lamivudine therapy [157]. There is now increasing evidence that with the appropriate therapy, recurrence rates may be significantly reduced in HBV recurrence. Other study showed the recurrence rate to be $12.7 \%$ [181]. HCC recurrence was detected by continuing elevation of the level of alpha-fetoprotein in the regular follow-up of the patient, confirmed by US detection of the recurrence in the graft. Additional investigations, including chest X-ray and brain scan, proved the presence of metastases. HCC recurrence represents a major risk factor in both graft failure and patient survival. The rate of recurrence of HCC after LT was dependent on the preoperative stage of the disease. Recurrent primary sclerosing cholangitis (PSC) was reported to be $20.0 \%[182,183]$ The clinical significance of recurrent PSC is that patients develop biliary strictures and it can mimic ductopenic rejection in presentation. Diagnosis relied on ERCP and liver biopsy. Single, dominant strictures in recurrent PSC are frequently amenable to dilatation. More extensive stricturing may require extensive surgical biliary reconstruction. Recurrent primary biliary cirrhosis (PBC) was reported to occur in $12.0 \%$ [184]. The detection was prompted by abnormal liver function tests on routine monitoring. Longer followup may be required to determine the clinical significance of recurrent PBC. Recurrent autoimmune hepatitis (AIH) was reported to occur between 25.0-33.0\% [185]. The clinical presentation of recurrence is characterized by increased transaminases (particularly AST) coupled with an increase in the serum IgG level and the presence of antiliver specific proteins or smooth muscle antibodies. Recurrence of AIH can be precipitated by the withdrawal of prednisolone from the immunosuppressive regimen and long-term corticosteroids are usually required in these situations [186].

\section{Problems of Graft failure after LT and risk factors for early and late graft failure}

Graft failure after LD remains an important problem as it leads to patient death or retransplantation. Graft failure was reported in the world literature to range between 9.0\%-27.0\% [187-190]. Graft failure was categorized as early, which occurred within one month, and late, which occurred after one month from transplantation. Primary nonfunction (PNF) which was reported to be the commonest cause of early graft failure in cadaveric liver transplantation [190], did not occur in LDLT due to the short cold ischemic time. Factors responsible for the low rate of early graft failure in the LDLT; optimum donor selection as regards age, sex, body mass index (BMI) and $\mathrm{ABO}$-compatibility; computer-assisted planning and decision making in donor segmental hepatectomy and optimum GRWR; short cold ischemic time; high level of expertise in the center; and timely detection of vascular, biliary and immunological complications responsible for early graft failure together with early and efficient management. Late graft failure cause were reported in many studies [150,191-193]. Most of the underlying causes of late graft failure include patients with CR which were not responding to treatment and patients with disease recurrence which is unavoidable. Therefore, both these complications constitute real problems in liver transplantation.

\section{Retransplantation as a solution for graft failure and a risk factor for graft failure}

In the field of LT, retransplantation may be needed to deal with patients for both early and late graft failure. Hepatic retransplantation is considered a risk factor for both graft and patient survival than primary transplantation. In 2003, Rosen found that, the age, serum bilirubin, creatinine, interval following primary transplantation as well as the UNOS status were predictive factors of outcome in patients with retransplantation [178]. In 2004, Postma studied 55 adult patients with retransplantation [194]. He found that, significant pre-transplant risk factors for unfavorable outcome include indications for transplantation other than HAT (especially CR), high creatinine level, high bilirubin level and low prothrombin level (high INR). He also found that, the era of transplantation affected the survival rate; survival at 1-year and 5-years improved from $56.0 \%$ and $48.0 \%$, respectively before 1996 to $89.0 \%$ and $81.0 \%$, respectively, after 1996 . This is obviously related to the experience gained in overcoming the technical difficulties in dissection of the failing graft and its blood vessels. He concluded that survival rate after retransplantation is improving through the years and is presently quite high approaching the results obtained in elective cases of primary transplantation. Further improvement might be achieved by improvement of renal function before the actual retransplantation. The advances in surgical and medical care of recipients which were achieved in recent years have significantly improved patient and graft survival after the primary transplantation [195]. This situation may give a chance for the original disease to recur in the graft. Therefore, the real problem in the future will be the increase in the number of cases needing retransplantation. Efforts are needed to reduce the risk factors before retransplantation in order to obtain better patient and graft survival. However, this aim may be difficult to obtain because after primary LDLT, donor candidates among the recipient's family will be limited, forcing the selection of marginal donors (older donors, ABOincompatible donors, small-for-size or steatotic grafts). This situation is undoubtly will be responsible for the significant graft failure and patient mortality obtained in cases of retransplantation.

\section{Mortality after LT}

Bacterial infection was a major cause of early patient mortality. Graft failure was the second major cause of mortality. Most of the mortalities occurred during hospital stay. This high rate of hospital mortality may be related to the preoperative status of the patient, the 
operative factors (the duration of the operation, blood loss, blood transfusion, cold ischemic time and worm ischemic time) and the intense immunosuppression therapy in the immediate postoperative period. The age of the recipient was a significant factor in mortality. The inferior results in adult patients compared to pediatric patients may be related to the common complications associated with the right lobe grafts usually performed in adult patients as well as the problems of small-for-size grafts. UNOS status $2 \mathrm{~A}$ was a significant factor in patient mortality among cases with end-stage liver disease. Retransplantation among patients with graft failure was a significant factor in patient mortality [196]. This may be related to poor preoperative status, difficult surgery and exposure to the complications of intense immunosuppressive therapy. Right lobe graft was a significant factor in patient mortality. This may be due to the high rate of vascular and biliary variations in the right lobe grafts, technical difficulties in the process of transplantation and the high incidence of postoperative complications.

\section{Summary and Conclusion}

Multiple factors were studied as risk factors for graft failure. Factors responsible for the low rate of early graft failure in the LDLT include optimum donor selection as regards age, sex, body mass index (BMI) and $\mathrm{ABO}$-compatibility; computer-assisted planning and decision making in donor segmental hepatectomy and optimum GRWR; short cold ischemic time; high level of expertise in the center; and timely detection of vascular, biliary and immunological complications responsible for early graft failure together with early and efficient management. Most of the underlying risk factors for late graft failure include patients with CR which were not responding to treatment and patients with disease recurrence which is unavoidable. Therefore, both these complications constitute real problems in liver transplantation.

It is important to remember that successful LT does not return a patient to normal. Rather a new disease "a transplanted liver" replaces the former disease. However, this new state allows patients a chance of both long-term survival and a more normal life style than were possible during the late stages of their liver disease. After LT patients must take immunosuppressive medications for the remainder of their lives. Discontinuation of the prescribed medications may lead to rejection and rapid deterioration in the patient's condition.

\section{References}

1. Hackl C, Schlitt HJ, Kirchner GI, Knoppke B, Loss M (2014) Liver transplantation for malignancy: current treatment strategies and future perspectives. World J Gastroenterol 20: 5331-5344.

2. Tamura S, Sugawara Y, Kokudo N (2014) Further expanding the criteria for HCC in living donor liver transplantation: the Tokyo University experience. Transplantation 8: S17-S20

3. Lee KW, Yi NJ, Suh KS (2014) Further expanding the criteria for HCC in living donor liver transplantation: when not to transplant: SNUH experience. Transplantation 8: S20-S23.

4. Kim WR, Therneau TM, Benson JT, Kremers WK, Rosen CB, et al. (2006) Deaths on the liver transplant waiting list: an analysis of competing risks. Hepatology 43: 345-351.

5. Shah SA, Levy GA, Adcock LD, Gallagher G, Grant DR (2006) Adult-to-adult living donor liver transplantation. Can J Gastroenterol 20: 339-343. [Crossref]

6. Kroencke S, Nashan B, Fischer L, Erim Y, Schulz KH (2014) Donor quality of life up to two years after living donor liver transplantation: a prospective study. Transplantation 97: 582-589.

7. Tanaka K, Ogura Y, Kiuchi T, Inomata Y, Uemoto S, et al. (2004) Living donor liver transplantation: Eastern experiences. HPB (Oxford) 6: 88-94.

8. Chen CL, Cheng YF, Yu CY, Ou HY, Tsang LL, et al. (2014) Living donor liver transplantation: the Asian perspective. Transplantation 97 Suppl 8: S3.
9. Marcos A (2000) Right-lobe living donor liver transplantation. Liver Transpl 6: S59-S63.

10. Brown RS (2008) Live donors in liver transplantation. Gastroenterology 134: 1802 1813.

11. Coelho JC, Parolin MB, Baretta GA, Pimentel SK, de Freitas AC, et al. (2005) Donor quality of life after living donor liver transplantation. Arquivos de gastroenterologia 42: 83-88.

12. Gruttadauria S, di Francesco F, Vizzini GB, Luca A, Spada M, et al. (2009) Early graft dysfunction following adult-to-adult living-related liver transplantation: predictive factors and outcomes. WJG 15: 4556-4560.

13. Azzam AZ, Tanaka K (2017) Outcome after living donor liver transplantation: A comprehensive retrospective analysis of the risk factors for morbidity, mortality and graft failure in a tertiary care center. Trends in Transplant 10: 1-12.

14. Castellvi JM, Xiol X, Guardiola J, Sabate I, Roca M, et al. (2004) Pretransplantation risk factors for graft loss after liver transplantation in cirrhotic patients; effect of cytomegalovirus serologic status. Transpl Int 17: 131-137.

15. Ishigami M, Honda T, Okumura A, Ishikawa T, Kobayashi M, et al. (2008) Use of the Model for End-Stage Liver Disease (MELD) score to predict 1-year survival of Japanese patients with cirrhosis and to determine who will benefit from living donor liver transplantation. J Gastroenterol 43: 363-368.

16. Habib S, Berk B, Chang CC, Demetris AJ, Fontes P, et al. (2006) MELD and prediction of post-liver transplantation survival. Liver Transpl 12: 440-447.

17. Brandão A, Fuchs SC, Gleisner AL, Marroni C, Zanotelli ML, et al. (2009) MELD and other predictors of survival after liver transplantation. Clin Transplant 23: 220-227. [Crossref]

18. Guo Z, He X, Wu L, Ju W, Hu A, et al. (2010) Model for end-stage liver disease versus the Child-Pugh score in predicting the post-transplant 3-month and 1-year mortality in a cohort of Chinese recipients. Surg Today 40: 38-45.

19. Tsunematsu I, Ogura Y, Inoue K, Koizumi A, Tanigawa N, et al. (2006) Quantitative survival model for short-term survival after adult-to-adult living donor liver transplantation. Liver Transpl 12: 904-911.

20. Mor E, Jennings L, Gonwa TA, Holman MJ, Gibbs J, et al. (1993) The impact of operative bleeding on outcome in transplantation of the liver. Surg Gynecol Obstet 176: 219-227. [Crossref]

21. Mueller AR, Platz KP, Krause P, Kahl A, Rayes N, et al. (2000) Perioperative factors influencing patient outcome after liver transplantation. Transpl Int 1: S158-S61.

22. Dahm F, Georgiev P, Clavien PA (2005) Small-for-size syndrome after partial liver transplantation: definition, mechanisms of disease and clinical implications. $\mathrm{Am} \mathrm{J}$ Transplant 5: 2605-2610.

23. Kiuchi T, Tanaka K, Ito T, Oike F, Ogura Y, et al. (2003) Small-for-size graft in living donor liver transplantation: how far should we go? Liver Transpl 9: S29-35. [Crossref]

24. Man K, Fan ST, Lo CM, Liu CL, Fung PC, et al. (2003) Graft injury in relation to graft size in right lobe live donor liver transplantation: a study of hepatic sinusoidal injury in correlation with portal hemodynamics and intragraft gene expression. Ann Surg 237: 256-264.

25. Soejima Y, Shimada M, Suehiro T, Hiroshige S, Ninomiya M, et al. (2003) Outcome analysis in adult-to-adult living donor liver transplantation using the left lobe. Liver Transpl 9: 581-586.

26. Jeon GS, Won JH, Wang HJ, Kim BW, Lee BM (2008) Endovascular treatment of acute arterial complications after living-donor liver transplantation. Clinical radiology 63: 1099-1105.

27. Azzam AZ, Tanaka K (2012) Management of vascular complications after living donor liver transplantation. Hepatogastroenterology 59: 182-186.

28. Jain A, Reyes J, Kashyap R, Dodson SF, Demetris AJ, et al. (2000) Long-term survival after liver transplantation in 4,000 consecutive patients at a single center. Ann Surg 232: 490-500.

29. Lo CM, Fan ST, Liu CL, Yong BH, Wong Y, et al. (2004) Lessons learned from one hundred right lobe living donor liver transplants. Ann Surg 240: 151-158. [Crossref]

30. Ito T, Kiuchi T, Egawa H, Kaihara S, Oike F, et al. (2003) Surgery-related morbidity in living donors of right-lobe liver graft: lessons from the first 200 cases. Transplantation 76: $158-163$.

31. Inomata Y, Uemoto S, Asonuma K, Egawa H (2000) Right lobe graft in living donor liver transplantation. Transplantation 69: 258-264. 
32. Maetani Y, Itoh K, Egawa H, Shibata T, Ametani F, et al. (2003) Factors influencing liver regeneration following living-donor liver transplantation of the right hepatic lobe. Transplantation 75: 97-102.

33. Kiuchi T, Kasahara M, Uryuhara K, Inomata Y, Uemoto S, et al. (1999) Impact of graft size mismatching on graft prognosis in liver transplantation from living donors. Transplantation 67: 321-327.

34. Inomata Y, Kiuchi T, Kim I, Uemoto S, Egawa H, et al. (1999) Auxiliary partial orthotopic living donor liver transplantation as an aid for small-for-size grafts in larger recipients. Transplantation 67: 1314-1319.

35. Lee SG, Park KM, Hwang S, Lee YJ, Kim KH, et al. (2002) Adult-to-adult living donor liver transplantation at the Asan Medical Center, Korea. Asian J Surg 25: 277-284.

36. Kaihara S, Ogura Y, Kasahara M, Oike F, You Y, et al. (2002) A case of adult-to-adult living donor liver transplantation using right and left lateral lobe grafts from 2 donors. Surgery 131: 682-684.

37. Lo CM, Fan ST, Liu CL, Wei WI, Lo RJ, et al. (1997) Adult-to-adult living donor liver transplantation using extended right lobe grafts. Ann Surg 226: 261-269.

38. Kelly DM, Demetris AJ, Fung JJ, Marcos A, Zhu Y, et al. (2004) Porcine partial liver transplantation: a novel model of the "small-for-size" liver graft. Liver Transpl 10: 253-263.

39. Ito T, Kiuchi T, Yamamoto H, Oike F, Ogura Y, et al. (2003) Changes in portal venous pressure in the early phase after living donor liver transplantation: pathogenesis and clinical implications. Transplantation 75: 1313-1317.

40. Lo CM, Liu CL, Fan ST (2003) Portal hyperperfusion injury as the cause of primary nonfunction in a small-for-size liver graft-successful treatment with splenic artery ligation. Liver Transpl 9: 626-628.

41. Boillot O, Delafosse B, Mechet I, Boucaud C, Pouyet M (2002) Small-for-size partial liver graft in an adult recipient; a new transplant technique. Lancet 359: 406-407.

42. Takada Y, Ueda M, Ishikawa Y, Fujimoto Y, Miyauchi H, et al. (2004) End-to-side portocaval shunting for a small-for-size graft in living donor liver transplantation. Liver Transpl 10: 807-810.

43. Adam R, Reynes M, Johann M, Morino M, Astarcioglu I, et al. (1991) The outcome of steatotic grafts in liver transplantation. Transplant Proc 23: 1538-1540.

44. Todo S, Demetris AJ, Makowka L, Teperman L, Podesta L, et al. (1989) Primary nonfunction of hepatic allografts with preexisting fatty infiltration. Transplantation 47: 903-905.

45. Fishbein TM, Fiel MI, Emre S, Cubukcu O, Guy SR, et al. (1997) Use of livers with microvesicular fat safely expands the donor pool. Transplantation 64: 248-251. [Crossref]

46. Chui AK, Shi LW, Rao AR, Anasuya A, Hagl C, et al. (2000) Primary graft dysfunction after liver transplantation. Transplant Proc 32: 2219-2220.

47. Hu KQ, Kyulo NL, Esrailian E, Thompson K, Chase R, et al. (2004) Overweight and obesity, hepatic steatosis, and progression of chronic hepatitis $\mathrm{C}$ : a retrospective study on a large cohort of patients in the United States. J Hepatol 40: 147-154.

48. Chen YS, Cheng YF, De Villa VH, Wang CC, Lin CC, et al. (2003) Evaluation of living liver donors. Transplantation 75: S16-19. [Crossref]

49. Marcos A, Fisher RA, Ham JM, Shiffman ML, Sanyal AJ, et al. (2000) Liver regeneration and function in donor and recipient after right lobe adult to adult living donor liver transplantation. Transplantation 69: 1375-1379.

50. Loinaz C, Gonzalez EM (2000) Marginal donors in liver transplantation. Hepatogastroenterology 47: 256-263.

51. Ploeg RJ, D'Alessandro AM, Knechtle SJ, Stegall MD, Pirsch JD, et al. (1993) Risk factors for primary dysfunction after liver transplantation--a multivariate analysis. Transplantation 55: 807-813.

52. Urena MA, Ruiz-Delgado FC, Gonzalez EM, Segurola CL, Romero CJ, et al. (1998) Assessing risk of the use of livers with macro and microsteatosis in a liver transplant program. Transplant Proc 30: 3288-3291.

53. Briceño J, Solórzano G, Pera C (2000) A proposal for scoring marginal liver grafts. Transpl Int 13 Suppl 1: S249-S252. [Crossref]

54. Rossi M, De Simone P, Peritore D, Iappelli M, Pretagostini R, et al. (2001) Liver transplantation: expanding the donor pool. Transplant Proc 33: 1307-1309.

55. Hayashi M, Fujii K, Kiuchi T, Uryuhara K, Kasahara M, et al. (1999) Effects of fatty infiltration of the graft on the outcome of living-related liver transplantation. Transplant Proc 31: 403 .
56. Soejima Y, Shimada M, Suehiro T, Kishikawa K, Yoshizumi T, et al. (2003) Use of steatotic graft in living-donor liver transplantation. Transplantation 76: 344-348.

57. Cho JY, Suh KS, Kwon CH, Yi NJ, Cho SY, et al. (2005) The hepatic regeneration power of mild steatotic grafts is not impaired in living-donor liver transplantation. Liver Transpl 11: 210-217.

58. Guggenheim j, Samuel D, Reynes M (1990) Liver transplantation across ABO blood group barriers. Lancet 336: 519-523.

59. Sanchez-Urdazpal L, Batts KP, Gores GJ, Moore SB, Sterioff S, et al. (1993) Increased bile duct complications in liver transplantation across the ABO barrier. Ann Surg 218: 152-158.

60. Hatano E, Terajima H, Yabe S, Asonuma K, Egawa H, et al. (1997) Hepatic artery thrombosis in living related liver transplantation. Transplantation 64: 1443-1446.

61. Farges O, Kalil AN, Samuel D, Saliba F, Arulnaden JL, et al. (1995) The use of ABOincompatible grafts in liver transplantation: a life-saving procedure in highly selected patients. Transplantation 59: 1124-1133.

62. Lo CM, Shaked A, Busuttil RW (1994) Risk factors for liver transplantation across the ABO barrier. Transplantation 58: 543-547.

63. Yandza T, Lambert T, Alvarez F, Gauthier F, Jacolot D, et al. (1994) Outcome of ABOincompatible liver transplantation in children with no specific alloantibodies at the time of transplantation. Transplantation 58: 46-50.

64. Hanto DW, Fecteau AH, Alonso MH, Valente JF, Whiting JF (2003) ABO-incompatible liver transplantation with no immunological graft losses using total plasma exchange, splenectomy, and quadruple immunosuppression: evidence for accommodation. Liver Transpl 9: 22-30.

65. Reding R, Veyckemans F, de Ville de Goyet J, de Hemptinne B, Carlier M, et al. (1992) ABO-incompatible orthotopic liver allografting in urgent indications. Surg Gynecol Obstet 174: 59-64.

66. Demetris AJ, Jaffe R, Tzakis A, Ramsey G, Todo S, et al. (1989) Antibody mediated rejection of human liver allografts: transplantation across $\mathrm{ABO}$ blood group barriers. Transplant Proc 21: 2217-2220.

67. White DJ, Gore SM, Barroso E, Calne RY (1987) The significance of ABO blood groups in liver transplant patients. Transplant Proc 19: 4571-4574.

68. Gordon RD, Iwatsuki S, Esquivel CO, Tzakis A, Todo S, et al. (1986) Liver transplantation across ABO blood groups. Surgery 100: 342-348. [Crossref]

69. Renard TH, Andrews WS (1992) An approach to ABO-incompatible liver transplantation in children. Transplantation 53: 116-121. [Crossref]

70. Belle SH, Beringer KC, Detre KM (1995) An update on liver transplantation in the United States: recipient characteristics and outcome. Clin Transpl. [Crossref]

71. Varela-Fascinetto G, Treacy SJ, Lillehei CW, Jonas MM, Lund DP, et al. (1999) Longterm results in pediatric ABO-incompatible liver transplantation. Transplant Proc 31: 467-468.

72. Renard TH, Shimaoka S, Le Bherz D, Conlin C, Andrews WS (1993) ABO incompatible liver transplantation in children: a prospective approach. Transplant Proc 25: 1953-1956.

73. Hashimoto T, Suzuki T, Shimizu Y, Otobe Y, Nakamura T, et al. (1998) ABOincompatible living related liver transplantation for fulminant hepatitis: report of a successful pediatric case with long-term follow-up. Transplant Proc 30: 3510-3512.

74. Ferriani VP, Barbosa JE, de Carvalho IF (1990) Serum haemolytic classical and alternative pathways of complement in infancy: age-related changes. Acta Paediatr Scand 79: 322-327. [Crossref]

75. Egawa H, Teramukai S, Haga H, Tanabe M, Fukushima M, et al. (2008) Present status of ABO-incompatible living donor liver transplantation in Japan. Hepatology 47:143-152.

76. Kasahara M, Kiuchi T, Takakura K, Uryuhara K, Egawa H, et al. (1999) Postoperative flow cytometry crossmatch in living donor liver transplantation: clinical significance of humoral immunity in acute rejection. Transplantation 67: 568-575. [Crossref]

77. Egawa H, Ohmori K, Haga H, Tsuji H, Yurugi K, et al. (2007) B-cell surface marker analysis for improvement of rituximab prophylaxis in $\mathrm{ABO}$-incompatible adult living donor liver transplantation. Liver Transpl 13: 579-588.

78. Kozaki K, Egawa H, Kasahara M, Oike F, Yoshizawa A, et al. (2005) Therapeutic strategy and the role of apheresis therapy for $\mathrm{ABO}$ incompatible living donor liver transplantation. Ther Apher Dial 9: 285-291.

79. Marino IR, Doyle HR, Aldrighetti L, Doria C, McMichael J, et al. (1995) Effect of donor age and sex on the outcome of liver transplantation. Hepatology 22: 1754-1762. 
80. Ikegami T, Nishizaki T, Yanaga K, Shimada M, Kishikawa K, et al. (2000)The impact of donor age on living donor liver transplantation. Transplantation 70: 1703-1707.

81. Kimura F, Miyazaki M, Suwa T, Kakizaki S (1996) Reduction of hepatic acute phase response after partial hepatectomy in elderly patients. Res Exp Med 196: 281-90.

82. Trey C (1972) The fulminant hepatic failure surveillance study. Brief review of the effects of presumed etiology and age of survival. Can Med Assoc J 106: 525-527.

83. Tanaka K, Uemoto S, Inomata Y, Tokunaga Y, Ueda M, et al. (1994) Living-related liver transplantation for fulminant hepatic failure in children. Transpl Int 1: S108-S110.

84. Hattori H, Higuchi Y, Tsuji M, Inomata Y, Uemoto S, et al. (1998) Living-related liver transplantation and neurological outcome in children with fulminant hepatic failure. Transplantation 65: 686-692.

85. Miwa S, Hashikura Y, Mita A, Kubota T, Chisuwa H, et al. (1999) Living-related liver transplantation for patients with fulminant and subfulminant hepatic failure. Hepatology 30: 1521-1526.

86. Emre S, Schwartz ME, Shneider B, Hojsak J, Kim-Schluger L, et al. (1999) Living related liver transplantation for acute liver failure in children. Liver Transpl Surg 5: 161-165.

87. Mack CL, Ferrario M, Abecassis M, Whitington PF, Superina RA, et al. (2001) Living donor liver transplantation for children with liver failure and concurrent multiple organ system failure. Liver Transpl 7: 890-895.

88. Lo CM, Fan ST, Liu CL, Wei WI, Chan JK, et al. (1999) Applicability of living donor liver transplantation to high-urgency patients. Transplantation 67: 73-77.

89. Nishizaki T, Hiroshige S, Ikegami T, Uchiyama H, Hashimoto K, et al. (2002) Livingdonor liver transplantation for fulminant hepatic failure in adult patients with a left-lobe graft. Surgery 131: S182- S189.

90. Testa G, Malago M, Nadalin S, Hertl M, Lang H, et al. (2002) Right-liver living donor transplantation for decompensated end-stage liver disease. Liver Transpl 8: 340-346.

91. Freeman RB (2003) The impact of the model for end-stage liver disease on recipient selection for adult living liver donation. Liver Transpl 9: S54-S59.

92. Todo S, Demetris AJ, Van Thiel D, Teperman L, Fung JJ, et al. (1991) Orthotopic liver transplantation for patients with hepatitis B virus-related liver disease. Hepatology 13: 619-626.

93. Markowitz JS, Martin P, Conrad AJ, Markmann JF, Seu P, et al. (1998) Prophylaxis against hepatitis $\mathrm{B}$ recurrence following liver transplantation using combination lamivudine and hepatitis B immune globulin. Hepatology 28: 585-589. [Crossref]

94. Dodson SF, de Vera ME, Bonham CA, Geller DA, Rakela J, et al. (2000) Lamivudine after hepatitis B immune globulin is effective in preventing hepatitis B recurrence after liver transplantation. Liver Transpl 6: 434-439.

95. Ghobrial RM, Amersi F, Farmer DG, Chen P, Anselmo DM, et al. (2002) Rapid and severe early HCV recurrence following adult living donor liver transplantation. Am J Transplant 2: $316 \mathrm{~A}$.

96. Gaglio PJ, Malireddy S, Russo M, Lapointe-Rudow D, Emond JC, et al. (2002) Hepatitis $\mathrm{C}$ recurrence in recipients of grafts from living vs cadaveric liver donors. Hepatology 36: 265A.

97. Bedossa P, Poynard T (1996) An algorithm for the grading of activity in chronic hepatitis C. The METAVIR Cooperative Study Group. Hepatology 24: 289-293.

98. Forman LM, Lucey MR (2001) Orthotopic liver transplantation for hepatitis C: Analysis of allograft survival using UNOS database. Am J Transplant 1: 156.

99. Charlton M, Seaberg E (1999) Impact of immunosuppression and acute rejection on recurrence of hepatitis C: results of the National Institute of Diabetes and Digestive and Kidney Diseases Liver Transplantation Database. Liver Transpl Surg 5: S107-S114.

100. Berenguer M, Ferrell L, Watson J, Prieto M, Kim M, et al. (2000) HCV-related fibrosis progression following liver transplantation: increase in recent years. $J$ Hepatol 32: 673-684.

101. Gregory TE, James T (2003) Role of Adult Living Donor Liver Transplantation in Patients With Hepatitis C. Liver Transplantation 9: S64-S68.

102. Mazzaferro V, Tagger A, Schiavo M, Regalia E, Pulvirenti A, et al. (2001) Prevention of recurrent hepatitis $\mathrm{C}$ after liver transplantation with early interferon and ribavirin treatment. Transplant Proc 33: 1355-1357.

103. Feray C, Samuel D, Gigou M, Paradis V, David MF, et al. (1995) An open trial of interferon alfa recombinant for hepatitis $\mathrm{C}$ after liver transplantation: antiviral effects and risk of rejection. Hepatology 22: 1084-1089.
104. El-Serag HB, Mason AC (1999) Rising incidence of hepatocellular carcinoma in the United States. $N$ Engl J Med 340: 745-750. [Crossref]

105. Ikeda K, Saitoh S, Koida I, Arase Y, Tsubota A, et al. (1993) A multivariate analysis of risk factors for hepatocellular carcinogenesis: a prospective observation of 795 patients with viral and alcoholic cirrhosis. Hepatology 18: 47-53.

106. Azzam AZ (2016) Updates in the Management of Hepatocellular Carcinoma. J Liver 5: $1-6$.

107. Llovet JM, Bustamante J, Castells A (1996) Liver transplantation for hepatocellular carcinoma. Results of a restrictive policy. Hepatology 24: 350A.

108. Azzam AZ1 (2015) Liver transplantation as a management of hepatocellular carcinoma. World J Hepatol 7: 1347-1354. [Crossref]

109. Okuda K, Ohtsuki T, Obata H, Tomimatsu M, Okazaki N, et al. (1985) Natura history of hepatocellular carcinoma and prognosis in relation to treatment. Study of 850 patients. Cancer 56: $918-28$.

110. Calvet X, Bruix J, Bru C, Gines P, Vilana R, et al. (1990) Natural history of hepatocellular carcinoma in Spain. Five year's experience in 249 cases. $J$ Hepatol 10: 311-317.

111. Gondolesi G, Munoz L, Matsumoto C, Fishbein T, Sheiner P, et al. (2002) Hepatocellular carcinoma: a prime indication for living donor liver transplantation. $J$ Gastrointest Surg 6: 102-107.

112. Miller CM, Gondolesi GE, Florman S, Matsumoto C, Munoz L, et al. (2001) One hundred nine living donor liver transplants in adults and children: a single-center experience. Ann Surg 234: 301-311

113. Mazzaferro V, Rondinara GF, Rossi G, Regalia E, De Carlis L, et al. (1994) Milan multicenter experience in liver transplantation for hepatocellular carcinoma. Transplant Proc 26: 3557-3560.

114. Iwatsuki S, Starzl TE, Sheahan DG, Yokoyama I, Demetris AJ, et al. (1991) Hepatic resection versus transplantation for hepatocellular carcinoma. Ann Surg 214: 221228.

115. Yao FY, Ferrell L, Bass NM, Bacchetti P, Ascher NL, et al. (2002) Liver transplantation for hepatocellular carcinoma: comparison of the proposed UCSF criteria with the Milan criteria and the Pittsburgh modified TNM criteria. Liver Transpl 8: 765-774.

116. Marsh JW, Dvorchik I, Bonham CA, Iwatsuki S (2000) Is the pathologic TNM staging system for patients with hepatoma predictive of outcome? Cancer 88: 538543. [Crossref]

117. Fung J, Marsh W (2002) The quandary over liver transplantation for hepatocellular carcinoma: the greater sin? Liver Transpl 8: 775-777.

118. Azzam AZ, Tanaka K (2011) Adoption of new selection criteria on living donor liver transplantation for hepatocellular carcinoma and their impact on the outcome. Hepatogastroenterology 58: 1873-1876.

119. Kaihara S, Kiuchi T, Ueda M, Oike F, Fujimoto Y, et al. (2003) Living-donor liver transplantation for hepatocellular carcinoma. Transplantation 75: S37-S40.

120. Yao FY, Ferrell L, Bass NM, Watson JJ, Bacchetti P, et al. (2001) Liver transplantation for hepatocellular carcinoma: expansion of the tumor size limits does not adversely impact survival. Hepatology 33: 1394-1403.

121. Emond JC, Renz JF (1994) Surgical anatomy of the liver and its application to hepatobiliary surgery and transplantation. Semin Liver Dis 14: 158-168.

122. Reichert PR, Renz JF, D'Albuquerque LA, Rosenthal P, Lim RC, et al. (2000) Surgical anatomy of the left lateral segment as applied to living-donor and split-liver transplantation: a clinicopathologic study. Ann Surg 232: 658-664.

123. Renz JF, Reichert PR, Emond JC (2000) Hepatic arterial anatomy as applied to living-donor and split-liver transplantation. Liver Transpl 6: 367-369.

124. Yamaoka Y, Ozawa K, Tanaka A, Mori K, Morimoto T, et al. (1991) New devices for harvesting a hepatic graft from a living donor. Transplantation 52: 157-160. [Crossref]

125. Broelsch CE, Emond JC, Whitington PF, Thistlethwaite JR, Baker AL, et al. (1990) Application of reduced-size liver transplants as split grafts, auxiliary orthotopic grafts, and living related segmental transplants. Ann Surg 212: 368-375.

126. Wozney P, Zajko AB, Bron KM, Point S, Starzl TE (1986) Vascular complications after liver transplantation: a 5-year experience. AJR Am J Roentgenol 147: 657-663.

127. Pawlak J, Ma $\AA$, kowski P, Michå̊, owiczB, et al. (1995) [Orthotopic liver transplantation in a patient with primary biliary cirrhosis]. Pol Tyg Lek 50: 53-55. [Crossref] 
128. Tzakis AG, Gordon RD, Shaw BW, Iwatsuki S, Starzl TE (1985) Clinical presentation of hepatic artery thrombosis after liver transplantation in the cyclosporine era. Transplantation 40: 667-671.

129. Pawlak J, Grodzicki M, Leowska E, Malkowski P, Michalowicz B, et al. (2003) Vascular complications after liver transplantation. Transplant Proc 35: 2313-2315.

130. Bakthavatsalam R, Marsh CL, Perkins JD, Levy AE, Healey PJ, et al. (2001) Rescue of acute portal vein thrombosis after liver transplantation using a cavoportal shunt at re-transplantation. Am J Transplant 1: 284-287.

131. Hirata M, Harihara Y, Hisatomi S, Miura Y, Yoshino H, et al. (2000) A case of esophageal variceal rupture following acute portal vein thrombosis three days after living-related liver transplantation. Transplant Proc 32: 2266-2268.

132. Marino IR, Esquivel CO, Zajko AB, Malatack J, Scantlebury VP, et al. (1989) Distal splenorenal shunt for portal vein thrombosis after liver transplantation. Am J Gastroenterol 84: 67-70.

133. Lee J, Ben-Ami T, Yousefzadeh D, Ramirez J, Funaki B, et al. (1996) Extrahepatic portal vein stenosis in recipients of living-donor allografts: Doppler sonography. AJR Am J Roentgenol 167: 85-90.

134. Dodd GD, Memel DS, Zajko AB, Baron RL, Santaguida LA (1994) Hepatic artery stenosis and thrombosis in transplant recipients: Doppler diagnosis with resistive index and systolic acceleration time. Radiology 192: 657-661.

135. Otte JB, de Ville de Goyet J, Sokal E, Alberti D, et al. (1990) Size reduction of the donor liver is a safe way to alleviate the shortage of size-matched organs in pediatric liver transplantation. Ann Surg 211: 146-157.

136. Inomoto T, Nishizawa F, Sasaki H, Terajima H, Shirakata Y, et al. (1996) Experiences of 120 microsurgical reconstructions of hepatic artery in living related liver transplantation. Surgery 119: 20-26.

137. Lerut J, Gordon RD, Iwatsuki S, Esquivel CO, Todo S, et al. (1987) Biliary tract complications in human orthotopic liver transplantation. Transplantation 43: 47-51.

138. Sanchez-Urdazpal L, Gores GJ, Ward EM, Maus TP, Wahlstrom HE, et al. (1992) Ischemic-type biliary complications after orthotopic liver transplantation. Hepatology 16: 49-53.

139. Stratta RJ, Wood RP, Langnas AN, Hollins RR, Bruder KJ, et al. (1989) Diagnosis and treatment of biliary tract complications after orthotopic liver transplantation. Surgery 106: 675-683.

140. Heffron TG, Emond JC, Whitington PF, Thistlethwaite JR, Stevens L, et al. (1992) Biliary complications in pediatric liver transplantation. A comparison of reduced-size and whole grafts. Transplantation 53: 391-395.

141. Cardot C, Candinas D, Miza D, Gunson B, Davison S, et al. (1995) Biliary complications after liver transplantation: Birmingham's experience. Transpl Int 8: 133-140.

142. Wiesner RH, Ludwig J, van Hoek B, Krom RA (1991) Current concepts in cellmediated hepatic allograft rejection leading to ductopenia and liver failure. Hepatology 14: 721-729.

143. Krom RA, Wiesner RH, Rettke SR, Ludwig J, Southorn PA, et al. (1989) The first 100 liver transplantations at the Mayo Clinic. Mayo Clin Proc 64: 84-94. [Crossref]

144. Ascher NL, Stock PG, Bumgardner GL, Payne WD, Najarian JS (1988) Infection and rejection of primary hepatic transplant in 93 consecutive patients treated with triple immunosuppressive therapy. Surg Gynecol Obstet 167: 474-484.

145. Oguma S, Belle S, Starzl TE, Demetris AJ (1989) A histometric analysis of chronically rejected human liver allografts: insights into the mechanisms of bile duct loss: direct immunologic and ischemic factors. Hepatology 9: 204-209.

146. Demetris AJ, Murase N, Lee RG, Randhawa P, Zeevi A, et al. (1997) Chronic rejection. A general overview of histopathology and pathophysiology with emphasis on liver, heart and intestinal allografts. Ann Transplant 2: 27-44.

147. Demetris AJ, Fung JJ, Todo S, McCauley J, Jain A, et al. (1992) Conversion of liver allograft recipients from cyclosporine to FK506 immunosuppressive therapy--a clinicopathologic study of 96 patients. Transplantation 53: 1056-1062.

148. Freese DK, Snover DC, Sharp HL, Gross CR, Savick SK, et al. (1991) Chronic rejection after liver transplantation: a study of clinical, histopathological and immunological features. Hepatology 13: 882-891.

149. Demetris AJ, Fung JJ, Todo S, McCauley J, Jain A, et al. (1991) FK 506 used as rescue therapy for human liver allograft recipients. Transplant Proc 23: 3005-3006.
150. Ludwig J, Wiesner RH, Batts KP, Perkins JD, Krom RA (1987) The acute vanishing bile duct syndrome (acute irreversible rejection) after orthotopic liver transplantation. Hepatology 7: 476-483.

151. Demetris A, Adams D, Bellamy C, Blakolmer K, Clouston A, et al. (2000) Update of the International Banff Schema for Liver Allograft Rejection: working recommendations for the histopathologic staging and reporting of chronic rejection. An International Panel. Hepatology 31: 792-799.

152. Wiesner RH, Batts KP, Krom RA (1999) Evolving concepts in the diagnosis, pathogenesis, and treatment of chronic hepatic allograft rejection. Liver Transpl Surg 5: $388-400$.

153. Demetris AJ, Qian S, Sun H, Fung JJ, Yagihashi A, et al. (1991) Early events in liver allograft rejection. Delineation of sites of simultaneous intragraft and recipient lymphoid tissue sensitization. Am J Pathol 138: 609-618.

154. Blakolmer K, Seaberg EC, Batts K, Ferrell L, Markin R, et al. (1999) Analysis of the reversibility of chronic liver allograft rejection implications for a staging schema. $\mathrm{Am}$ J Surg Pathol 23: 1328-1339.

155. Wiesner RH, Ludwig J, Van Hoek B, Krom R (1992) Chronic Hepatic Allograf Rejection: a review of ductopenic rejection and the vanishing bile duct syndrome. In: Paul LC, Solez K (Eds) Organ Transplantation: long-term results. Marcel Dekker, New York pp. 197-216.

156. Steinhoff G, Wonigeit K, Pichlmayr R (1988) Analysis of sequential changes in major histocompatibility complex expression in human liver grafts after transplantation. Transplantation 45: 394-401.

157. Yusoff IF, House AK, De Boer WB, Ferguson J, Garas G, et al. (2002) Disease recurrence after liver transplantation in Western Australia. J Gastroenterol Hepatol 17: 203-207.

158. Markin RS, Langnas AN, Donovan JP, Zetterman RK, Stratta RJ (1991) Opportunistic viral hepatitis in liver transplant recipients. Transplant Proc 23: 1520-1521.

159. Paya CV, Hermans PE, Washington JA, Smith TF, Anhalt JP, et al. (1989) Incidence, distribution, and outcome of episodes of infection in 100 orthotopic liver transplantations. Mayo Clin Proc 64: 555-564.

160. Lumbreras C, Lizasoain M, Moreno E, Aguado JM, Gomez R, et al. (1992) Major bacterial infections following liver transplantation: a prospective study. Hepatogastroenterology 39: 362-365.

161. Jacobs F, Van de Stadt J, Bourgeois N, Struelens MJ, De Prez C, et al. (1989) Severe infections early after liver transplantation. Transplant Proc 21: 2271-2273.

162. Kusne S, Dummer JS, Singh N, Iwatsuki S, Makowka L, et al. (1988) Infections after liver transplantation. An analysis of 101 consecutive cases. Medicine 67: 132-143.

163. Colonna JO, Winston DJ, Brill JE, Goldstein LI, Hoff MP, et al. (1988) Infectious complications in liver transplantation. Arch Surg 123: 360-364. [Crossref]

164. Kim JH, Perfect JR (1989) Infection and cyclosporine. Rev Infect Dis 11: 677-690. [Crossref]

165. Wajszczuk CP, Dummer JS, Ho M, Van Thiel DH, Starzl TE, et al. (1985) Fungal infections in liver transplant recipients. Transplantation 40: 347-353.

166. Viviani MA, Tortorano AM, Malaspina C, Colledan M, Paone G, et al. (1992) Surveillance and treatment of liver transplant recipients for candidiasis and aspergillosis. Eur J Epidemiol 8: 433-436. [Crossref]

167. Schröter GP, Hoelscher M, Putnam CW, Porter KA, Starzl TE (1977) Fungus infections after liver transplantation. Ann Surg 186: 115-122. [Crossref]

168. Castaldo P, Stratta RJ, Wood RP, Markin RS, Patil KD, et al. (1991) Clinical spectrum of fungal infections after orthotopic liver transplantation. Arch Surg 126: 149-156.

169. Wiens M, Schmidt CA, Lohmann R, Oettle H, Blumhardt G, et al. (1993) Cytomegalovirus disease after liver transplantation: diagnostics and therapy. Transplant Proc 25: 2673-2674.

170. Stratta RJ, Shaefer MS, Markin RS, Wood RP, Kennedy EM, et al. (1989) Clinica patterns of cytomegalovirus disease after liver transplantation. Arch Surg 124 :14431449.

171. Sido B, Hofmann WJ, Otto G, Amann K, Arnold JC, et al. (1993) Cytomegalovirus infection of the liver graft early after transplantation: incidence and clinical relevance. Transplant Proc 25: 2671-2672.

172. Bronsther O, Makowka L, Jaffe R, Demetris AJ, Breinig MK, et al. (1988) Occurrence of cytomegalovirus hepatitis in liver transplant patients. J Med Virol 24: 423-434. 
173. Alessiani M, Kusne S, Fung JJ, Torre-Cisneros J, Jain A, et al. (1991) CMV infection in liver transplantation under cyclosporine or FK 506 immunosuppression. Transplant Proc 23: 3035-3037. [Crossref]

174. Egawa H, Ohishi T, Arai T, Inomata Y, Uemoto S, et al. (1998) Application of in situ hybridization technique for quantitative assessment of ongoing symptomatic Epstein-Barr virus infection after living related liver transplantation. Clin Transplant 12: $116-122$.

175. Van Thiel DH, Gavaler JS (1987) Recurrent disease in patients with liver transplantation: when does it occur and how can we be sure? Hepatology 7 : 181-183. [Crossref]

176. Van Thiel DH, Carr B, Iwatsuki S, Tzakis A, Fung JJ, et al. (1991) Liver transplantation for alcoholic liver disease, viral hepatitis, and hepatic neoplasms. Transplant Proc 23: 1917-1921.

177. Rolles K, Williams R, Neuberger J, Calne R (1984) The Cambridge and King's College Hospital experience of liver transplantation, 1968-1983. Hepatology 4: 50S-5S.

178. Rosen HR, Prieto M, Casanovas-Taltavull T, Cuervas-Mons V, Guckelberger O, et al. (2003) Validation and refinement of survival models for liver retransplantation. Hepatology 38: 460-469.

179. Fukumoto T, Berg T, Ku Y, Bechstein WO, Knoop M, et al. (1996) Viral dynamics of hepatitis $\mathrm{C}$ early after orthotopic liver transplantation: evidence for rapid turnover of serum virions. Hepatology 24: 1351-1354.

180. Dumortier J, Scoazec JY, Chevallier P, Boillot O (2004) Treatment of recurrent hepatitis $\mathrm{C}$ after liver transplantation: a pilot study of peginterferon alfa- $2 \mathrm{~b}$ and ribavirin combination. $J$ Hepatol 40: 669-674.

181. Todo S, Furukawa H (2004) Living donor liver transplantation for adult patients with hepatocellular carcinoma: experience in Japan. Ann Surg 240: 451-459.

182. Graziadei IW, Wiesner RH, Marotta PJ, Porayko MK, Hay JE, et al. (1999) Longterm results of patients undergoing liver transplantation for primary sclerosing cholangitis. Hepatology 30: 1121-1127.

183. Gow PJ, Chapman RW (2000) Liver transplantation for primary sclerosing cholangitis. Liver 20: 97-103.
184. Balan V, Batts KP, Porayko MK, Krom RA, Ludwig J, et al. (1993) Histological evidence for recurrence of primary biliary cirrhosis after liver transplantation. Hepatology 18: 1392-1398.

185. Jeffrey GP, Brind AM, Ormonde DG, Frazer CK, Ferguson J, et al. (1999) Management of biliary tract complications following liver transplantation. Aust $N$ Z J Surg 69: 717-722.

186. Wright HL, Bou-Abboud CF, Hassanein T, Block GD, Demetris AJ, et al. (1992) Disease recurrence and rejection following liver transplantation for autoimmune chronic active liver disease. Transplantation 53: 136-139.

187. D'Alessandro AM, Ploeg RJ, Knechtle SJ, Pirsch JD, Stegall MD, et al. (1993) Retransplantation of the liver--a seven-year experience. Transplantation 55: 10831087. [Crossref]

188. Knechtle S, D'Alessandro A, Reed A, Sollinger H, Pirsch J, et al. (1991) Liver retransplantation: the University of Wisconsin experience. Transplant Proc 23: 3.

189. Shaw BW, Gordon RD, Iwatsuki S, Starzl TE (1985) Retransplantation of the liver Semin Liver Dis 5: 394-401.

190. Fangmann J, Ringe B, Hauss J, Pichlmayr R (1993) Hepatic retransplantation: the Hannover experience of two decades. Transplant Proc 25: 1077-1078.

191. Ludwig J, Batts KP, MacCarty RL (1992) Ischemic cholangitis in hepatic allografts. Mayo Clin Proc 67: 519-526. [Crossref]

192. Demetris AJ (1992) Ischemic cholangitis. Mayo Clin Proc 67: 601-602. [Crossref]

193. Demetris AJ, Jaffe R, Starzl TE (1987) A review of adult and pediatric post-transplant liver pathology. Pathol Annu 22 Pt 2: 347-386. [Crossref]

194. Postma R, Haagsma EB, Peeters PM, van den Berg AP, Slooff MJ (2004) Retransplantation of the liver in adults: outcome and predictive factors for survival. Transpl Int 17: 234-240. [Crossref]

195. Keeffe EB (2001) Liver transplantation: current status and novel approaches to liver replacement. Gastroenterology 120: 749-762.

196. Iwatsuki S, Starzl TE, Gordon RD, Esquivel CO, Todo S, et al. (1987) Late mortality and morbidity after liver transplantation. Transplant Proc 19: 2373-2377.

Copyright: $\odot 2018$ Azzam A. This is an open-access article distributed under the terms of the Creative Commons Attribution License, which permits unrestricted use, distribution, and reproduction in any medium, provided the original author and source are credited. 